\title{
NEUGODNI I NOVI SADRŽAJI U FUNKCIJI KREATIVNOSTI: PO ČEMU SE STUDENTI UMJETNOSTI RAZLIKUJU OD OSTALIH?
}

\author{
Irena J. Ristić \\ Fakultet dramskih umetnosti, Univerzitet umetnosti u Beogradu \\ Bulevar umetnosti 20. 11000 Beograd, Srbija \\ ir.ristic@gmail.com \\ Miloš Milošević \\ Fakultet dramskih umetnosti, Univerzitet umetnosti u Beogradu \\ Bulevar umetnosti 20. 11000 Beograd, Srbija \\ milosmilosevic80@yahoo.com
}

\begin{abstract}
Sažetak
Dosadašnja istraživanja djelomično potvrđuju psihodinamske pretpostavke da neugodni i novi sadržaji mogu poticajno djelovati na kreativnost. Upitno je, međutim, na koji način bliskost sadržaja, pojedine dimenzije emocionalnog doživljaja, i kvalitete emocija djeluju na produkciju izrazito kreativnih osoba i pokazuju li oni izvjesne specifičnosti tijekom generativnih procesa. $U$ ovom istraživanju ispituje se stupanj i vrsta povezanosti između kreativnosti odgovora i kvalitete emocija (radosti, žalosti, straha, srdžbe, iznenađenja i gađenja), dimenzija emocionalnog doživljaja (valencije i uzbuđenosti) i bliskosti sadržaja kod različitih studentskih populacija. Eksperiment je izveden uz sudjelovanje 59 studenata, a za vizualnu stimulaciju je izabrano 40 fotografija, tako da su vrijednosti dimenzija i kvalitete emocionalnog doživljaja sustavno varirane. Od ispitanika je traženo da ocijene koliko im je blizak sadržaj fotografija, a zatim da smisle najkreativniji naslov za svaku od njih. Kreativnost naslova je mjerena putem koeficijenata kreativnosti i izuzetnosti baziranih na statističkoj procjeni originalnosti. Rezultati potvrđuju umjerenu negativnu povezanost kreativnosti s valencijom, s bliskošću sadržaja i s radošću, zatim umjerenu pozitivnu povezanost kreativnosti s uzbuđenošću, žalošću, strahom, srdžbom, iznenađenjem i gađenjem, kao i specifičnosti kreativnog procesa studenata umjetnosti, kod kojih novina i iznenađenje preuzimaju primat pred drugim dimenzijama i kvalitetama emocionalnog doživljaja.
\end{abstract}

Ključne riječi: kreativnost, primarne emocije, bliskost sadržaja, dimenzije emocionalnog doživljaja, umjetnička produkcija 


\section{UVOD}

Iako ne postoji konsenzus u definiranju pojma emocija (Izard, 2010), kao ni pojma kreativnosti (Mandić i Ristić, 2013; Sternberg, Grigorenko i Singer, 2004), emociju možemo definirati kao subjektivni i aktualni odgovor na vanjski podražaj ili mentalnu reprezentaciju, manifestiran kroz specifična ponašanja i fiziološke promjene, ali i kroz subjektivne doživljaje (Cacioppo, Berntson, Larsen, Poehlmann i Ito, 2000). S druge strane, ako nastojimo objediniti različite pristupe, kreativnost možemo definirati kao međuigru između sposobnosti, procesa i sredine, tijekom koje osoba ili skupina stvara vidljive produkte koji su istodobno novi i primjenjivi, po mjerilima društvenog okvira u kome nastaju (Plucker i Beghetto, 2004).

U istraživanjima u kojima je ispitivana struktura emocionalnog doživljaja pokazano je da se kombiniranjem nekoliko fundamentalnih dimenzija mogu opisati sva emocionalna stanja, a među njima su ključne: valencija koja govori o stupnju (ne)ugode koju određena stimulacija evocira, i uzbuđenost (arousal) koja upućuje na razinu napetosti i pobuđenosti u određenom emocionalnom stanju, a govori o stupnju neuralne aktivnosti (Mauss i Robinson 2009; Mehrabian i Russell, 1974; Russell i Mehrabian, 1977). Dimenzionalnom pristupu u proučavanju emocija suprotstavljen je kategorijalni: pojedini autori smatraju da je svođenje emocionalnog doživljaja samo na dvije dimenzije simplifikacija koja ne dopušta precizan opis doživljaja koji leže u osnovi različitih emocija. Umjesto toga emocije treba promatrati kao diskretne kategorije, tako da se moraju uzeti u obzir kvalitete primarnih emocija (Ekman, 1992). Rezultati suvremenih studija otkrivaju neurofiziološke mehanizme koji upućuju na utemeljenost dimenzionalnog, ali i kategorijalnog pristupa proučavanju emocija (Posner, Russell i Peterson, 2005; Tettamanti, Rognoni, Cafiero, Costa, Galati i Perani 2012; Viinikainen, Kätsyri i Sams, 2011). Kako cilj ovog rada nije razriješiti ključne dileme o prirodi i strukturi emocionalnog doživljaja, već produbiti dosadašnje spoznaje o ulozi emocija u kreativnoj produkciji, pored bazičnih dimenzija pažnju ćemo posvetiti i kvalitetama emocija: žalosti, radosti, strahu, srdžbi, iznenađenju i gađenju.

\section{Raspoloženi za kreativnost?}

Nalazi ispitivanja utjecaja induciranih raspoloženja na stupanj kreativnosti sugeriraju da kreativno mišljenje može biti potaknuto dobrim raspoloženjem (Baas, DeDreu i Nijstad, 2008; Benjafield, 1997; Isen, 1993, 1998; Isen i Baron, 1991; Shapiro i Weisberg, 1999) i inhibirano lošim, jer se smanjuje razina fluentnosti tijekom smišljanja novih ideja (Vosburg, 1998a, 1998b). Pozitivni sadržaji su bolje integrirani u memoriji nego sadržaji koji se doživljavaju negativno ili neutralno, i upravo zbog toga dobro raspoloženje omogućuje širenje aktivacije i povezivanje udaljenih asocijacija ključnih za kreativno mišljenje (Isen, 2005). Generativni procesi mogu biti osnaženi hipomaničnim stanjima umjerenog intenziteta (Jami- 
son, 1993), a dobro raspoloženje utječe na kognitivne procese, najprije na kategorizaciju. Kada prepoznaju sličnosti, raspoloženi ispitanici koriste šire kategorije, a kada se fokusiraju na razlike, lakše se prebacuju na uže (Hirt, Melton, McDonald i Harackiewicz, 1996; Showers i Cantor, 1985), na temelju čega se izvodi zaključak da vedra raspoloženja mogu djelovati na fleksibilnost ispitanika kada prave kategorizaciju, kao i na pristup većem broju neobičnih i raznolikih informacija. Čini se da su ispitanici spremniji eksplorirati nove procedure i mogućnosti kada su dobro raspoloženi, što može povećati šanse za javljanje kreativnih rješenja (Ruder i Bless, 2003; Russ, 1993; Unkelbach, Fiedler, Bayer, Stegmuller i Danner, 2008). Potvrđena je i značajna interakcija raspoloženja i vremena produkcije u odnosu na različite faze procesa (Kaufmann i Vosburg, 2002). Pozitivni osjećaji vode do superiornih kreativnih postignuća u ranoj fazi produkcije, dok kontrolirani i negativni osjećaji vode do boljeg postignuća u kasnijoj fazi produkcije. Može se zaključiti da su pozitivna raspoloženja poželjna u uvjetima bez ograničenja, ali kudikamo manje produktivna u ograničenim okolnostima. Međutim i kada nema nikakvog vremenskog ograničenja, pokazano je da dobro raspoloženje vodi do smanjenog ulaganja napora prilikom rješavanja problema, jer ispitanici brže odustaju od potrage za informacijama koje su relevantne za daljnji rad (Martin, Ward, Achei i Wyer, 1993). S druge strane, upravo tenzija i nezadovoljstvo mogu biti preduvjeti kreativnog mišljenje. Frekventnost suicidalnih misli, kao snažan indikator negativnih raspoloženja, u pozitivnoj je korelaciji sa sposobnošću potrage za problemom (Mraz i Runco, 1994; Runco, 1998). Kreativnost ispitanika može se povećati pod utjecajem negativnih afektivnih stanja umjerenog intenziteta (George i Zhou, 2002; Feist, 1999; Forgas, 2002; Russ, Robins i Christiano, 1999; Vosburg i Kaufmann, 1998). Različiti nalazi o efektima pozitivnih i negativnih raspoloženja mogu se objasniti djelovanjem kontekstualnih faktora, posebno kada raspoloženje sudionika uvjetuje procjenu vlastite kreativnosti (Martin i Stoner, 1996). Treba imati u vidu i da postoji mnoštvo načina za mjerenje kreativnosti (Fulgosi, 2005), a efekti induciranih raspoloženja mogu ovisiti o različitim tipovima zadataka koji se u istraživanjima koriste (Davis, 2009). Također, istraživanja o efektima induciranih raspoloženja više govore o optimalnim, hipotetičkim uvjetima za izvođenje kreativnih zadataka ili određenih operacija unutar njih, a manje o dinamici samog postupka i ulozi emocija u povezivanju sadržaja koji čine osnovu kreativnog čina. Sandra Russ podsjeća da postoje dvije vrste afektivnih procesa koji su važni za kreativnost. Prvi se odnose na sposobnost pojedinca da razmišlja ili izražava ideje o sadržajima koji nose emocionalni naboj, dok se drugi odnosi na neposredna iskustva određenih afektivnih stanja (Russ, 1993). Ova distinkcija djelomično može objasniti i kontradiktornost dosadašnjih rezultata. Nalazi o stimulativnom efektu pozitivnih emocionalnih stanja mahom se odnose na trenutačno djelovanje induciranih raspoloženja, bez uvida u mehanizme koji omogućuju da duboko pohranjeni, ili čak potisnuti emocionalni doživljaji postanu stožer kreativnog postupka. O djelovanju potisnutih emocija opsežnije pišu autori psihodinamske orijentacije. 


\section{Psihodinamsko tumačenje kreativnosti}

Po klasičnoj psihoanalitičkoj teoriji, kreativnost izranja iz tenzije između svjesne realnosti i nesvjesnih nagona, a sam čin stvaranja može se objasniti mehanizmom sublimacije (Freud, 1908). Podrijetlo kreativnosti, dakle, treba tražiti u intrapsihičkom konfliktu, dok sublimacija omogućuje pojedincu da nesvjesne, mahom zabranjene želje izrazi u transformiranom obliku, na način koji je prihvatljiv javnosti. Kada govori o umjetnicima i piscima, Freud ističe "gipkost potiskivanja" i njihovu sposobnost da određena emocionalna stanja izražavaju kroz kreativnu produkciju (Freud, 1908). Unatoč kritikama, psihoanalitička tumačenja kreativnosti postupno stječu dostojnu empirijsku validaciju. Pokazano je da ispitanici koji učestalo koriste mehanizam sublimacije otkrivaju viši stupanj kreativnosti od drugih (Domino, Short, Evans i Romano, 2002; Vaillant i Vaillant, 1990) i da izrazito kreativne osobe pokazuju viši stupanj anksioznosti, kao i da koriste veći broj različitih obrambenih kategorija koje su u pozitivnoj korelaciji s mjerama fluentnosti (Carllson, 2002). Uvidi o funkcionalnoj regresiji objašnjavaju pristup sadržajima primarnog procesa koji izranjaju iz intrapsihičkog konflikta i nose snažan emocionalni naboj (Kris, 1952). Ističe se i uloga agresivnih nagona u objašnjenju sadržaja koji nastaju kao derivati sublimacije tijekom kreativnog procesa, i time se upotpunjuje Freudova prvobitna ideja o preusmjeravanju seksualne energije (Bergler, 1945). Tijekom kreativnog postupka, može se očekivati da slike i misli primarnog procesa izazivaju odbojnost ili neugodne emocije (Rotenberg, 2010). Pritom ih osoba ne doživljava kao dio osobnog iskustva, kao bliske, logične i poznate, već kao da su nametnute izvana, daleke i nedostupne prepoznavanju, mada mogu izazivati izvjestan stupanj anksioznosti, zbog napetosti koja se izoštrava. Ove psihodinamske pretpostavke djelomično su potvrđene: kada se studentima umjetnosti izlažu fotografije koje izazivaju nelagodu, njihovi odgovori postaju kreativniji (Ristić i Milošević, 2017). Ostalo je, međutim, upitno da li i na koji način dimenzija uzbuđenosti i bliskost sadržaja mogu djelovati na kreativni proces. U regresijskom modelu pokazano je da su valencija i uzbuđenost vrlo dobri prediktori bliskosti. Veza valencije i bliskosti je pozitivna, a uzbuđenosti i bliskosti je negativna, što navodi na zaključak da se upravo sadržaji koji izazivaju neugodne emocije i uzbuđenost - ne prepoznaju kao bliski, a da pritom mogu rezultirati višim stupnjem kreativnosti (Ristić i Milošević, 2017). Otvaraju se još dva pitanja: kako kvalitete primarnih emocija djeluju na stupanj kreativnosti, i razlikuju li se pripadnici umjetničke populacije od ostalih po ulozi valencije, uzbuđenosti, bliskosti sadržaja i specifične kvalitete primarnih emocija u kreativnom procesa. Biometrijski eksperimenti pokazuju da izrazito kreativne osobe kao što su umjetnici otkrivaju izvjesne specifičnosti: nešto višu osnovnu (resting) razinu neuralne aktivnosti, u usporedbi s ostalima, ali i nešto nižu razinu tijekom prve faze kreativne produkcije kada dominira geneza novih ideja (Martindale, 2005), pritom preferiraju novitete (Houston i Mednick, 1963), i pokazuju potrebu za stimulacijom (Farley, 1985). 
Sukladno dosadašnjim nalazima možemo pretpostaviti da postoji povezanost kreativnosti kako s bliskošću sadržaja i dimenzijama emocionalnog doživljaja, tako i s različitim kvalitetama emocija (H1). Izlaganje sadržaja koji evociraju neugodnost i viši stupanj uzbuđenosti, a koji se pritom doživljavaju ne kao bliski, već kao novi i nepoznati, rezultiraju višim stupnjem kreativnosti (H1a). Izlaganje sadržaja koji evociraju neugodne emocije specifične kvalitete, kao što su žalost, srdžba, strah i gađenje djeluju stimulativno i rezultiraju kreativnijim odgovorima, dok ugodne emocije drugačije kvalitete, kao što je radost, rezultiraju nižim stupnjem kreativnosti (H1b). Također, možemo pretpostaviti da dimenzije emocionalnog doživljaja i kvalitete primarnih emocija, kao i bliskost sadržaja koji evociraju emocije različito djeluju na izrazito kreativne osobe, u odnosu na pripadnike opće populacije (H2). Kod osoba koje generiraju odgovore značajno višeg stupnja kreativnosti, postojat će jača povezanost između kreativnosti odgovora i bliskosti sadržaja (H2a), dimenzija emocionalnog doživljaja (H2b) i kvalitete emocija (H2c).

\section{METODA}

U istraživanju su sudionici producirali odgovore na zadatak otvorenog tipa koji je po strukturi i sadržaju blizak zadacima kakvi se pojavljuju u okviru kreativne produkcije.

\section{Sudionici}

U istraživanju su sudjelovali studenti različitih usmjerenja, ukupno njih 59, od toga su 22 studenti Visoke škole elektrotehnike i računarstva (VISER), 10 muškaraca i 12 žena, prosječne dobi od 21,5 godina, a 37 su studenti Fakulteta dramskih umetnosti u Beogradu (FDU), prosječne dobi 22 godine, 18 muškaraca i 19 žena. Veličina uzorka određena je na temelju analiza statističke snage za Pearsonovu korelaciju, za prag vjerojatnosti za odbacivanje nulte hipoteze $\alpha($ dvostranu $)=0,05$, snage $\mathrm{f}=0,80$ i za veliki očekivani efekt $\rho=0,5$ (Hulley, Cummings, Browner, Grady i Newman 2013; Kohn, 2016). ${ }^{1}$

Studenti VISER-a odabrani su sa smjera Elektroničkog poslovanja, koji uključuje populaciju nespecifičnih interesa bez iskustva u umjetničkoj produkciji i

1 Prema navedenim pretpostavkama željena veličina uzorka je 29 ispitanika. Također, urađena je i analiza statističke snage za analizu varijance (tri razine faktora A uz kombinaciju od 3 razine faktora $B$ na svakoj razini faktora $A$ ), pomoću $\alpha=0,05$, snage $f=$ 0,80 , i za srednji očekivani efekt $(\delta=0,75)$ (Cohen, 1969; Friendly, 2016), što je pokazalo da je željena veličina uzorka 12 ispitanika na svakom od 3 razine faktora A. 
istraživačkom radu, tako da po kreativnim predispozicijama mogu predstavljati opću studentsku populaciju, dok su studenti FDU-a odabrani kao izuzetni pojedinci koji se tijekom studija obučavaju u umjetničkoj produkciji i pripadaju izrazito kreativnoj populaciji. Prema smjeru koji pohađaju, studenti FDU-a se dalje mogu podijeliti u dvije skupine: njih 17 su studenti umjetnosti, dok njih 20 studiraju produkciju i menadžment u kulturi. Ukupan uzorak je formiran tako da se može raslojiti na tri poduzorka: umjetnička, producentska (oba pripadaju izrazito kreativnoj populaciji) i opća studentska populacija, kako bi se provjerile eventualne razlike između njih.

Ispitanici su volonterski sudjelovali u eksperimentu. Prije početka su bili pismeno i usmeno informirani o zadacima i proceduri, da će podaci biti korišteni isključivo anonimno i da se u svakom trenutku mogu povući iz eksperimenta bez posljedica. Izvođenje eksperimenta odobreno je od dekanata FDU-a i VISER-a, i u skladu je s Kodeksom profesionalne etike Univerziteta umetnosti u Beogradu i s Etičkim načelima i kodeksom propisanim od strane APA.

\section{Podražaji}

Uzorak podražaja je oblikovan odabirom 40 realističnih fotografija iz standardiziranog seta pod nazivom Nencki Affective Picture System. NAPS obuhvaća 1356 fotografija koje induciraju emocije različite kvalitete gradirane po dimenzijama valencije i uzbuđenosti; učestalo se koristi u suvremenim psihološkim istraživanjima jer je prošao fazu validacije i ima dobre metrijske karakteristike (Marchewka, Żurawski, Jednoróg i Grabowska 2014). Za potrebe ovog istraživanja odabrane su fotografije lica, životinja, objekata, scena i krajolika, dok su vrijednosti valencije i uzbuđenosti sustavno varirane, ali tako da obuhvaćaju i različite kvalitete emocija: žalost, strah, radost, srdžbu, iznenađenje i gađenje (Slika 1).

\section{Postupak}

Izlaganje fotografija je izvedeno putem plazma monitora veličine 42 inča. Nakon bilježenja demografskih varijabli, studentima su, jedna po jedna, izlagane odabrane fotografije i od njih je traženo da ih ocijene po varijabli bliskosti. Ispitanici su bliskost ocjenjivali devetostupanjskim unipolarnim skalama, koje su varirale od 1 (potpuno nepoznato) preko 5 (neutralno) do 9 (potpuno poznato). Nakon toga, fotografije su ponovo izlagane jedna po jedna, a zadatak studenata bio je da za svaku smisle najkreativniji naslov (Čorko, 2003) i upišu ga u namjenski list za odgovore. Nije bilo vremenskog ograničenja za smišljanje naslova. Studenti su radili samostalno, ali su bili podijeljeni u četiri skupine, tako da su fotografije izlagane balansiranim redoslijedom. 


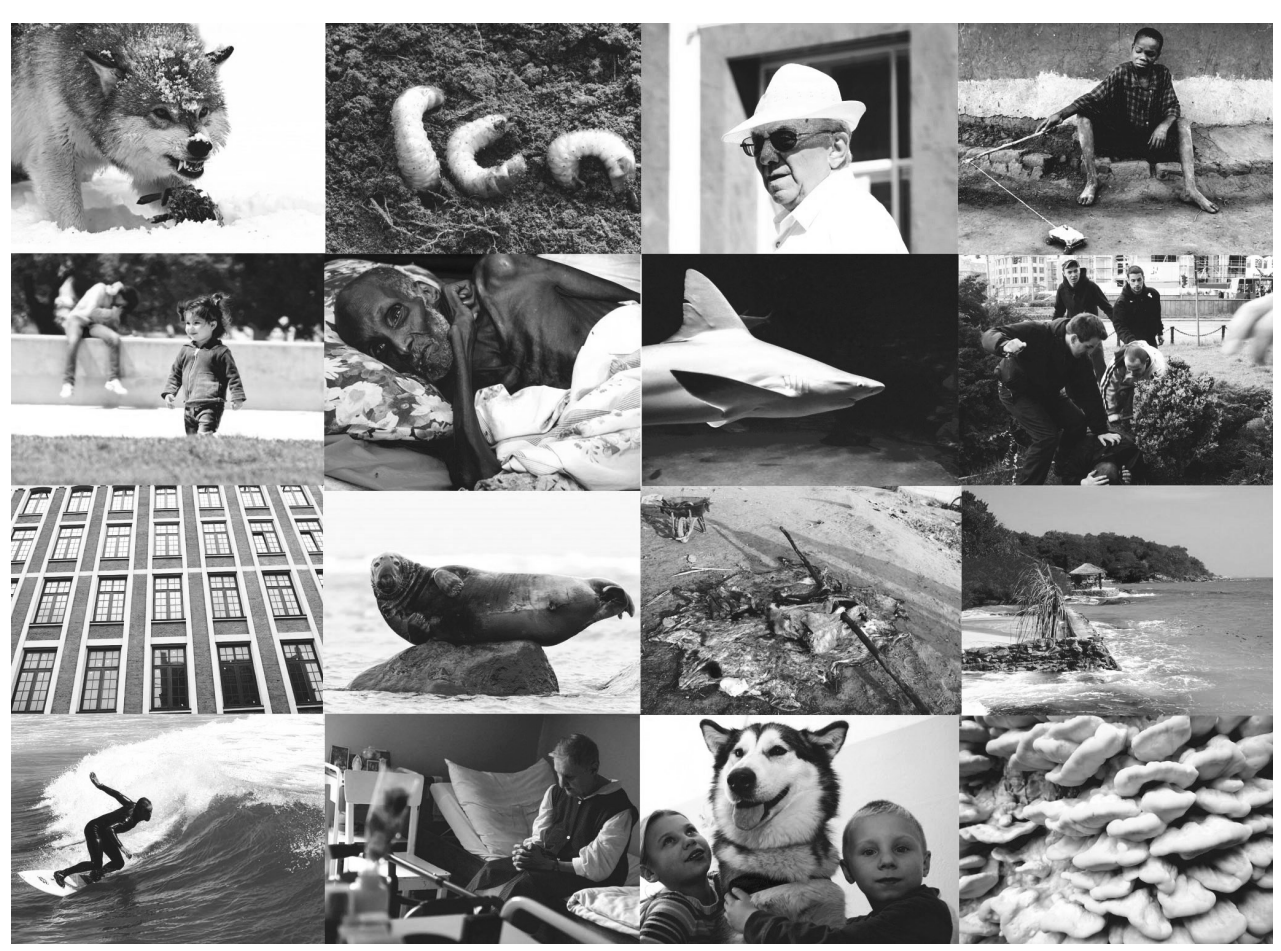

Slika 1. Primjeri podražaja koji su odabrani iz Nencki Affective Picture System (NAPS): fotografije koje induciraju emocije različite kvalitete gradirane po dimenzijama valencije $\mathrm{i}$ uzbuđenosti.

\section{Mjere}

Iz standardiziranih mjera unutar NAPS baze preuzete su mjere valencije $\mathrm{i}$ uzbuđenosti, te mjere različitih kvaliteta emocija za svaku odabranu fotografiju. Mjera bliskosti sadržaja pojedinačne fotografije dobivena je na temelju izravne procjene sudionika tijekom eksperimentalne sesije.

Mjerenje kreativnosti naslova izvršeno je putem koeficijenata kreativnosti i izuzetnosti koji predstavljaju numeričke izraze stupnja kreativnosti zasnovane na lako i objektivno mjerljivim aspektima kreativnog produkta (Milošević i Ristić, 2016). Predloženi koeficijenti izvode se na temelju statističke procjene originalnosti, a u prethodnim istraživanjima pokazalo se da imaju dobre metrijske karakteristike. Relativna standardna greška ocjene prosječne vrijednosti u populaciji manja je od $3 \%$ od prosječne vrijednosti u uzorku $[\mathrm{M}=0,42, \mathrm{SE}=0,01]$, raspodjela ne odstupa značajno od normalne (Milošević i Ristić, 2017), uz zadovoljavajući stupanj pouzdanosti $[\alpha=0,82]$, i valjanosti, što je potvrđeno i pozitivnom korelacijom visokog stupnja s konsenzualnom tehnikom procjene kreativnosti [CAT: 
$\mathrm{r}=0,80, \mathrm{p}<0,001]$. Kako nalaže postupak kvantifikacije, u ovom istraživanju najprije je izvršena kategorizacija odgovora po sličnosti, potom provjera intencionalnosti svakog izuzetnog odgovora, uz eventualne korekcije kategorija, i nakon toga se pristupilo izračunavanju koeficijenta kreativnosti putem količnika dobivenih i mogućih različitih odgovora na razini varijable $[K=N / n]$, kao i koeficijenta izuzetnosti pojedinačnih odgovora, putem količnika broja 1 i broja ispitanika koji su dali isti odgovor: $[\mathrm{Ki}=1 / \mathrm{m}]$. Dobivena aritmetička sredina koeficijenata izuzetnosti svih ispitanika jednaka je koeficijentu kreativnosti varijable $[\mathrm{M}=(\mathrm{K} 1$ $+\mathrm{K} 2+\ldots \ldots . \mathrm{Kn}) / \mathrm{n}=\mathrm{K}]$ (Milošević i Ristić, 2017).

Kvantificirani podaci obrađeni su deskriptivnom, korelacijskom i analizom varijance radi provjere postavljenih hipoteza.

\section{REZULTATI}

Rezultati deskriptivne statističke analize pokazuju da veličine skewnesa i kurtosisa ne odstupaju značajno od normalne raspodjele, a relativna standardna greška ocjene prosječne vrijednosti u populaciji iznosi $2 \%$ od prosječne vrijednosti u uzor$\mathrm{ku}[\mathrm{M}=0,65, \mathrm{SE}=0,13]$ (Tablica 1).

Kada se promatra uzorak u cjelini, rezultati korelacijske analize pokazuju postojanje statistički značajne negativne povezanosti umjerenog stupnja između kreativnosti i valencije, kao i kreativnosti i bliskosti, dok je povezanost kreativnosti i uzbuđenosti pozitivna, niža, doduše, ali također statistički značajna (Tablica 2). Isto tako, potvrđena je pozitivna povezanost umjerenog stupnja između kreativnosti i žalosti, i kreativnosti i srdžbe, a nešto nižeg stupnja između kreativnosti i straha, iznenađenja i gađenja. Također, statistički je značajna negativna povezanost umjerenog stupnja između kreativnosti i radosti (Tablica 2).

Kako bi se efekti varijable bliskosti promatrali odvojeno od efekata varijabli dimenzija emocionalnog doživljaja i kvalitete emocija, provjerene su i parci-

Tablica 1. Rezultati deskriptivne statističke analize koeficijenta kreativnosti za uzorak u cjelini i za studentske poduzorke, na nivou 40 fotografija

\begin{tabular}{|c|c|c|c|c|c|c|c|c|c|}
\hline & \multirow{2}{*}{$\frac{\text { Min }}{\text { Statistik }}$} & \multirow{2}{*}{$\frac{\text { Max }}{\text { Statistik }}$} & \multicolumn{2}{|c|}{$M$} & \multirow{2}{*}{$\frac{S D}{\text { Statistik }}$} & \multicolumn{2}{|c|}{ Skewness } & \multicolumn{2}{|c|}{ Kurtosis } \\
\hline & & & Statistik & Std. Gr. & & Statistik & Std. Gr. & Statistik & Std. Gr. \\
\hline KK & 0,51 & 0,83 & 0,65 & 0,013 & 0,08 & 0,61 & 0,374 & $-0,66$ & 0,733 \\
\hline KK.UM & 0,41 & 0,92 & 0,72 & 0,015 & 0,10 & $-0,57$ & 0,374 & 1,69 & 0,733 \\
\hline KK.PR & 0,51 & 0,90 & 0,69 & 0,016 & 0,10 & 0,25 & 0,374 & $-0,81$ & 0,733 \\
\hline KK.OP & 0,35 & 0,85 & 0,55 & 0,017 & 0,11 & 0,56 & 0,374 & 0,22 & 0,733 \\
\hline
\end{tabular}

Legenda: Koeficijent kreativnosti za 40 fotografija (varijabli) za cijeli uzorak (KK) te za poduzorke: umjetnička (KK.UM), producentska (KK.PR) i opća studentska populacija (KK.OP). 
Tablica 2. Povezanost između kreativnosti, bliskosti sadržaja, dimenzija emocionalnog doživljaja i različite kvalitete emocija za uzorak u cjelini i za studentske poduzorke, na nivou 40 fotografija

\begin{tabular}{lcccccccccc}
\hline Pearson $r$ & & Blisk. & Uzb. & Val. & Radost & Žalost & Strah & Srdžba & Iznen. & Gađe. \\
\hline KK & $\mathrm{r}$ & $-0,46^{* *}$ & $0,32^{*}$ & $-0,54^{* * *}$ & $-0,50^{* * *}$ & $0,52^{* * *}$ & $0,33^{*}$ & $0,48^{* *}$ & $0,38^{*}$ & $0,37^{*}$ \\
& $\mathrm{p}$ & 0,003 & 0,045 & 0,000 & 0,001 & 0,001 & 0,037 & 0,002 & 0,016 & 0,020 \\
\hline \multirow{2}{*}{ KK.UM } & $\mathrm{r}$ & $-0,51^{* * *}$ & 0,22 & $-0,21$ & $-0,17$ & 0,26 & 0,18 & 0,17 & $0,31^{*}$ & 0,09 \\
& $\mathrm{p}$ & 0,001 & 0,168 & 0,203 & 0,287 & 0,099 & 0,267 & 0,294 & 0,050 & 0,575 \\
\hline KK.PR & $\mathrm{r}$ & $-0,225$ & 0,29 & $-0,61^{* * *}$ & $-0,58^{* *}$ & $0,53^{* *}$ & $0,36^{*}$ & $0,56^{* *}$ & 0,26 & $0,41^{* *}$ \\
& $\mathrm{p}$ & 0,125 & 0,075 & 0,000 & 0,000 & 0,001 & 0,024 & 0,000 & 0,099 & 0,009 \\
\hline \multirow{2}{*}{ KK.OP } & $\mathrm{r}$ & $-0,36^{*}$ & 0,24 & $-0,42^{* *}$ & $-0,38^{*}$ & $0,40^{*}$ & 0,23 & $0,36^{*}$ & $0,31^{*}$ & $0,32^{*}$ \\
& $\mathrm{p}$ & 0,023 & 0,133 & 0,008 & 0,016 & 0,010 & 0,150 & 0,024 & 0,048 & 0,045 \\
\hline \multirow{2}{*}{ Bliskost } & $\mathrm{r}$ & & $-0,51^{* *}$ & $0,50^{* * *}$ & $0,43^{* *}$ & $-0,41^{* *}$ & $-0,58^{* *}$ & $-0,72^{* *}$ & $-0,33^{*}$ & $-0,57^{* *}$ \\
& $\mathrm{p}$ & & 0,001 & 0,001 & 0,005 & 0,008 & 0,000 & 0,000 & 0,036 & 0,000 \\
\hline
\end{tabular}

Legenda: Koeficijent kreativnosti na nivou 40 podražaja za cijeli uzorak (KK), kao i za poduzorke (KK.UM. KK.PR, KK.OP), bliskost sadržaja (Bliskost), dimenzije emocionalnog doživljaja (Uzbuđenost i Valencija) i kvalitete emocionalnog doživljaja (Radost, Žalost, Strah, Srdžba, Iznenađenje i Gađenje).

jalne korelacije. Kada se parcijalizira efekt bliskosti sadržaja, ostaju kao statistički značajne samo povezanosti kreativnosti i valencije, radosti, žalosti i srdžbe, dok uz parcijalizaciju efekta uzbuđenosti, valencije, radosti, žalosti, straha, srdžbe, iznenađenja i gađenja, veza između kreativnosti i bliskosti sadržaja prestaje biti statistički značajna.

Evidentne razlike između umjetničke, producentske i opće studentske populacije u pogledu povezanosti kreativnosti s valencijom, uzbuđenošću, bliskošću i pojedinim kvalitetama emocija (tablice 2 i 3 ) potvrđene su i rezultatima dvofaktorskih multivarijatnih analiza varijance, $u$ kojima su provjereni efekti pojedinačnih dimenzija, kao i dvostruke i trostruke interakcije faktora valencije, uzbuđenosti i studijskog usmjerenja.

Potvrđen je glavni efekt faktora studijskog usmjerenja: sudionici se međusobno razlikuju po stupnju kreativnosti, ovisno o studijskom usmjerenju $[\mathrm{F}(2,36)=$ $51,05 ; \mathrm{p}<0,001]$. Opća studentska populacija značajno podbacuje glede stupnja kreativnosti u odnosu na studente FDU-a, među kojima ne postoje razlike (Graf 1).

Potvrđena je značajnost interakcije faktora studijski smjer i valencija $[F(4,74)$ $=2,71 ; \mathrm{p}<0,036]$. Kreativnost umjetničke i producentske populacije na različit način varira u odnosu na stupanj izraženosti valencije $[\mathrm{F}(2,37)=3,76 ; \mathrm{p}<0,033]$. Dok kreativnost studenata produkcije opada s porastom valencije, studenti umjetnosti otkrivaju tek neznatna variranja (Graf 2). 


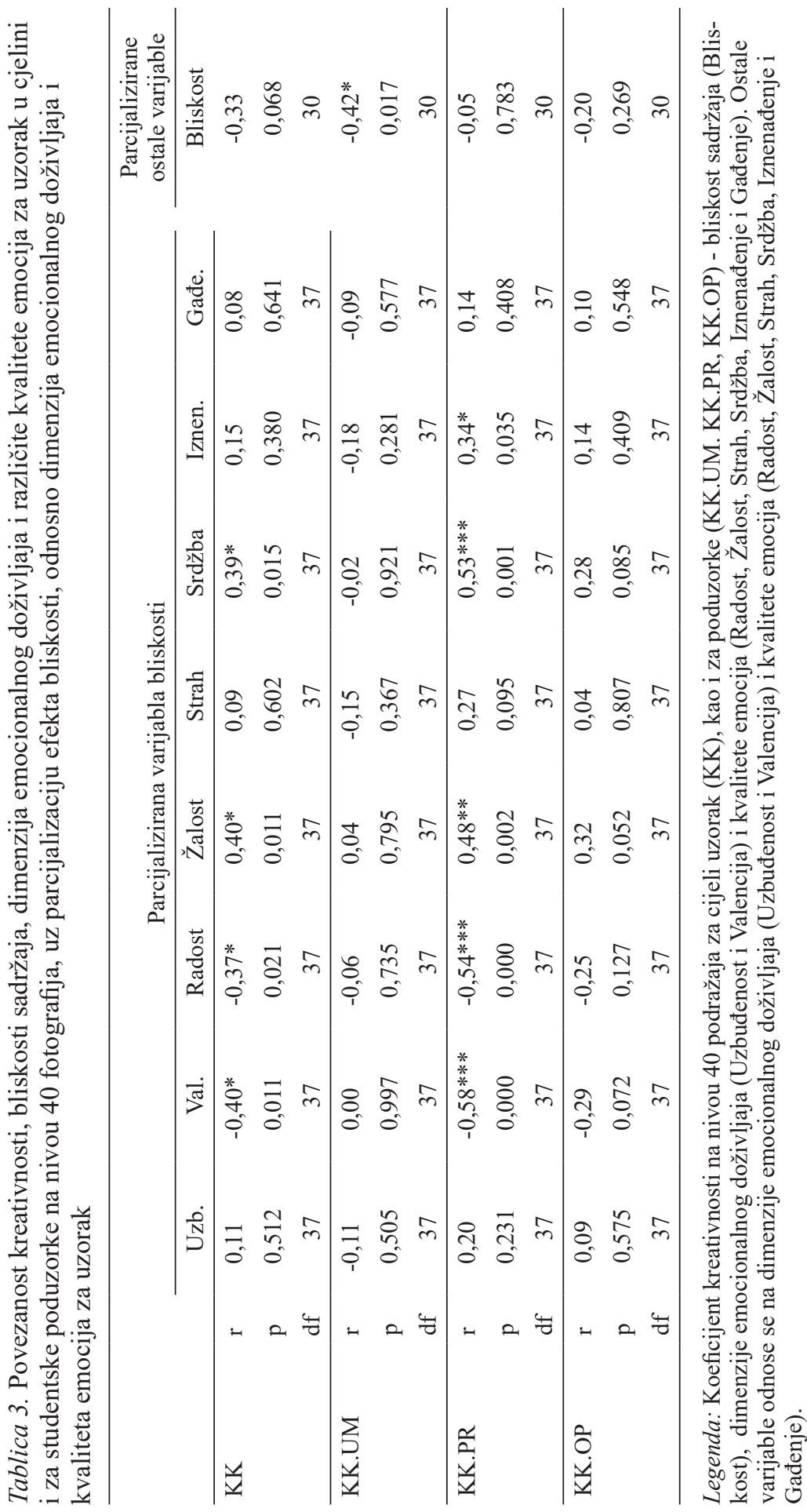




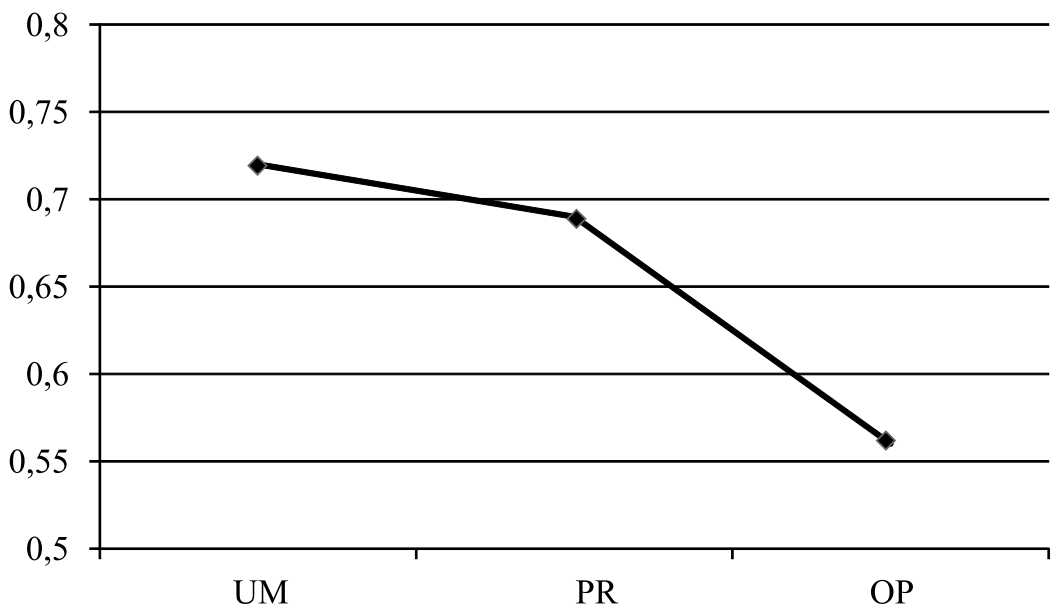

Graf 1. Prosječne vrijednosti koeficijenta kreativnosti između tri poduzorka: umjetničke (UM), producentske (PR) i opće studentske populacije (OP)

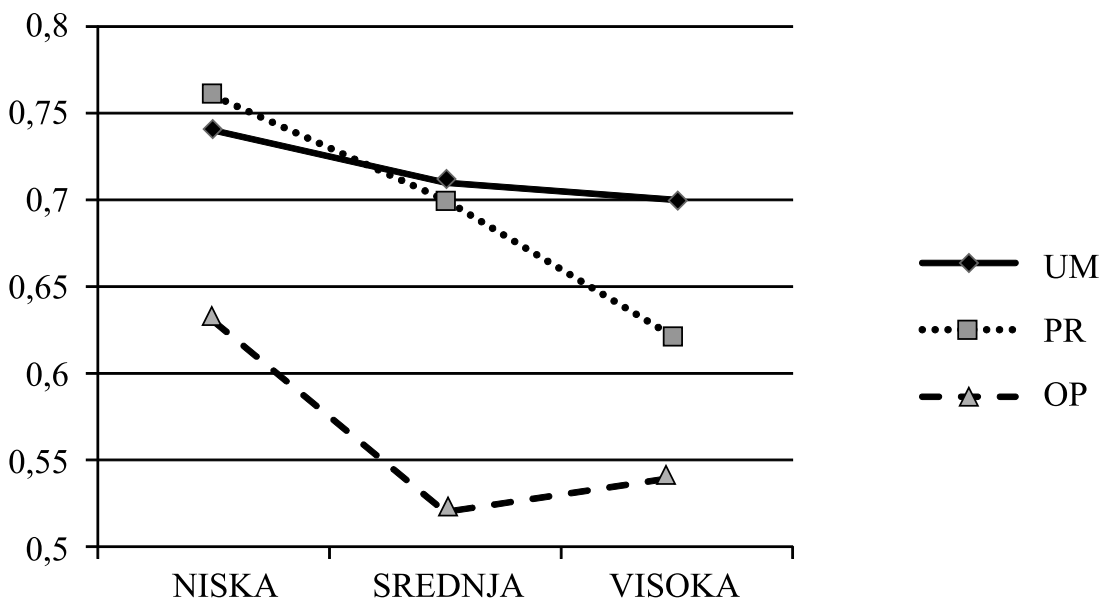

Graf 2. Razlike prosječnih vrijednosti koeficijenta kreativnosti za tri studentska poduzorka na dimenziji VALENCIJE

Testovi su pokazali da kreativnost umjetničke i opće studentske populacije na različit način varira u odnosu na stupanj izraženosti dimenzije uzbuđenosti [F (2, $37)=3,84 ; \mathrm{p}<0,031]$ (Graf 3).

Interakcije faktora studijski smjer i pojedine kvalitete emocija nisu se pokazale kao statistički značajne. Jedina interakcija za koju je potvrđena statistička značajnost 


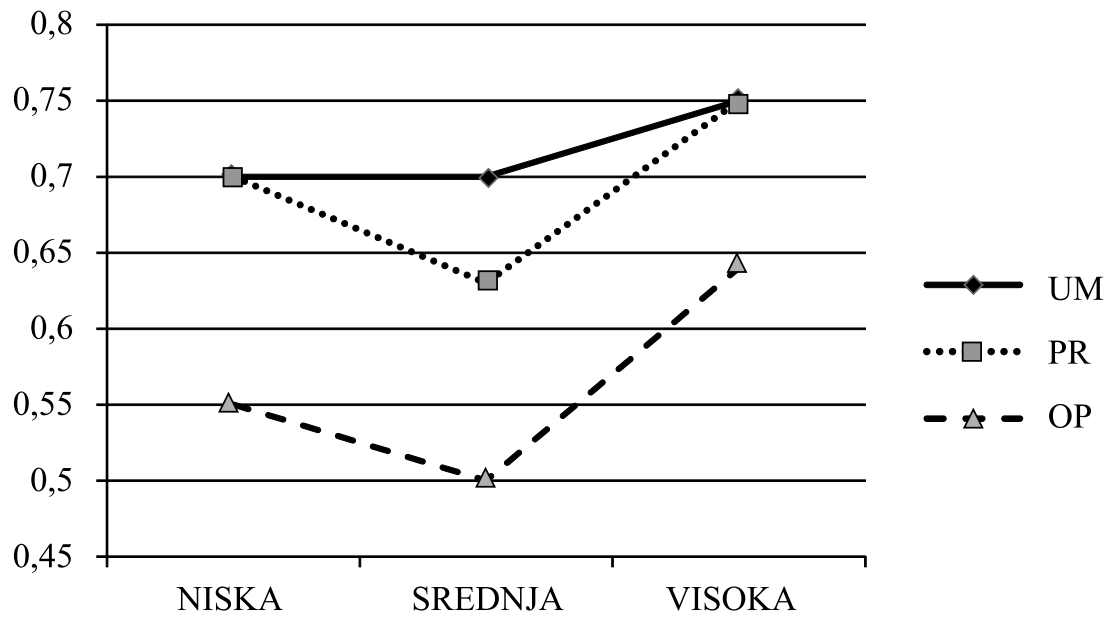

Graf 3. Razlike između prosječnih vrijednosti koeficijenta kreativnosti za tri studentska poduzorka na dimenziji UZBUĐENOSTI

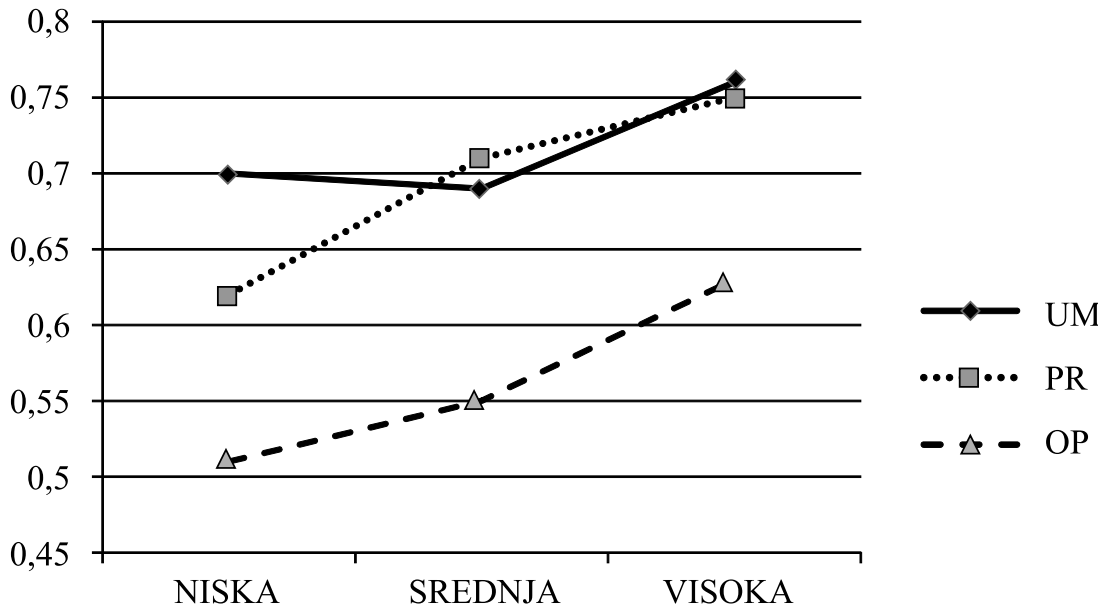

Graf 4. Razlike između prosječnih vrijednosti koeficijenta kreativnosti za tri studentska poduzorka u odnosu na emociju ŽALOSTI

evidentirana je kod variranja kreativnosti studenata u odnosu na izraženost žalosti (Graf 4). Naime, kreativnost studenata umjetnosti i produkcije različito varira u odnosu na razinu žalosti koja je sadržajima evocirana $[F(2,37)=3,44 ; p<0,043]$. 


\section{RASPRAVA}

Na temelju rezultata korelacijske analize možemo u potpunosti prihvatiti prvu hipotezu. Kada se promatra uzorak u cjelini, dileme iz prethodnih studija sada su razriješene: pobuđujući sadržaji koji izazivaju nelagodu i koji se doživljavaju kao nepoznati i novi - rezultiraju višim stupnjem kreativnosti (Ristić i Milošević, 2017). Nalazi su i proširili dosadašnje uvide, jer je potvrđeno da je kreativnost povezana sa svim mjerenim kvalitetama emocija. Fotografije koje evociraju žalost i srdžbu djeluju stimulativno na kreativnost, a u nešto slabijem stupnju i fotografije koje izazivaju strah, gađenje i iznenađenje, dok se suprotan efekt dobiva kada se promatraju fotografije koje evociraju radost. Pretpostavljamo da je veći uzorak ispitanika i podražaja u ovom istraživanju omogućio preciznije mjerenje i manje upitne zaključke nego ranije.

Dobiveni nalazi mogli bi biti objašnjeni mehanizmom sublimacije. Potisnuti sadržaji izazivaju nelagodu, ne prepoznaju se kao bliski, ali mogu djelovati pobuđujući zbog izvjesnog stupnja anksioznosti koja se izoštrava, kao okidač svih mehanizama obrane, pa i sublimacije (Baumeister, Dale i Sommer, 1998; Freud, 1908). U prilog ovome govore i rezultati korelacijske analize potvrđujući da se neugodne, pobuđujuće, iznenađujuće stvari koje nas ljute, rastužuju, plaše i izazivaju gađenje percipiraju kao nepoznate i obrnuto. Treba imati u vidu da se sam mehanizam zasniva, ne samo na zabranjenim seksualnim željama koje su potisnute i zakopane u nesvjesnom, već i na agresivnosti preusmjerenoj, maskiranoj i transformiranoj kroz aktivnosti koje su socijalno poželjne, a mogu biti i gratificirane (Bergler, 1945; Domino i sur., 2002; Kim, Zeppenfeld i Cohen, 2013).

Najpotpunije objašnjenje uloge neugodnih emocija u kreativnom procesu ponudila je Melanie Klein (1935) teorijom reparacije. Ishodi ranih agresivnih fantazija i potisnuti doživljaji krivnje zbog gubitka objekta mogu biti stožer kreativnog postupka. Kreativnost, dakle potječe iz želje da se otklone efekti vlastite destruktivnosti, da se reparira objekt koji je mržnjom uništen. Stoga sublimacija nije samo prosta neutralizacija seksualne energije, već usmjeravanje libidonoznih impulsa da pobijede one agresivne (Klein, 1935). Teorija reparacija može objasniti povezanost kreativnosti s negativnom valencijom i uzbuđenošću, sa sadržajima koji nisu dostupni svijesti te se doživljavaju kao nepoznati i strani, a djeluju posebno stimulativno kada izazivaju žalost i srdžbu, o čemu svjedoče rezultati ove studije.

Rezultati korelacijske analize za svaki poduzorak posebno, upućuju na mogućnost da obrasci povezanosti kreativnosti i mjerenih varijabli nisu isti kod umjetničke, producentske i opće studentske populacije. Za kreativni proces studenata umjetnosti izgleda da je ključna novina jer je kreativnost kod njih negativno povezana s dimenzijom bliskosti, a pozitivno s emocijom iznenađenja. Ova veza opstaje čak i kada se parcijalizira efekt varijabli dimenzija i kvalitete emocionalnog doživljaja. Za studente produkcije značajne su neugodne emocije: postaju kreativniji kada promatraju slike koje izazivaju žalost, strah, srdžbu i gađenje, dok sadržaji 
koji izazivaju radost smanjuju njihovu kreativnost. Novina kod njih čini se da nema važnost, jer kreativnost studenata produkcije nije povezana s bliskošću sadržaja niti s emocijom iznenađenja. Opisane veze opstaju i kada se parcijalizira efekt varijable bliskosti, jedino se veza s varijablama gađenja i straha izgubi, što govori o njihovoj prirodi, odnosno većoj oslonjenosti na novinu sadržaja. Studenti općeg usmjerenja također pokazuju izvjesne specifičnosti: kreativniji su kada promatraju neugodne slike koje izazivaju žalost, srdžbu i gađenje, za razliku od onih koje izazivaju radost, ali su potaknuti i nepoznatim sadržajima koji iznenađuju. Veze kreativnosti i izmjerenih varijabli slabije su nego kod umjetničkog i producentskog uzorka, a kada se parcijaliziraju efekti bliskosti sadržaja ili varijabli dimenzija i kvalitete emocionalnog doživljaja, sve opisane veze kod opće populacije prestaju biti statistički značajne. Ovaj nalaz nam govori o međusobnoj isprepletenosti i povezanosti ocjene bliskosti i emocionalnog doživljaja u kreativnom procesu kod opće populacije. Po tome se i razlikuje od visoko kreativne populacije, gdje bliskost i emocionalni doživljaj pokazuju veliki stupanj autonomije kada je riječ o njihovoj povezanosti s kreativnošću.

Analizom varijance potvrđene su razlike između poduzoraka. Sasvim očekivano, opća studentska populacija pokazuje značajno niži nivo kreativnosti od studenata FDU-a. Uzimajući ovaj nalaz u obzir i prethodno spomenute nalaze korelacijske analize, može se prihvatiti i druga hipoteza. Nešto je manje očekivana značajnost provjeravanih interakcija. Rezultati potvrđuju da studenti umjetnosti otkrivaju tek neznatna variranja kada je riječ o dimenzijama emocionalnog doživljaja i da se po tome značajno razlikuju ne samo od opće studentske populacije, čija kreativnost pokazuje tendenciju "skoka" s visokim stupnjem uzbuđenosti, već se razlikuju i od svojih kolega koji studiraju produkciju, i čija kreativnost opada s povećanjem valencije. Ostaje dojmljivo do koje mjere je kreativni proces budućih umjetnika manje osjetljiv na variranje dimenzija emocionalnog doživljaja u odnosu na druge studentske poduzorke. Možemo zaključiti da je kognitivna stimulacija daleko važnija za njihovu kreativnost nego emocionalni doživljaj vezan za sadržaje koji su polazište procesa, odnosno da je njihov kreativni proces osjetljiviji na nove i manje poznate sadržaji koji se doživljavaju kao izazov i djeluju stimulativno. Rezultati su u skladu s biometrijskim nalazima o preferenciji novine i potrebi za stimulacijom koju pokazuju izrazito kreativni ljudi (Farley, 1985; Houston i Mednick, 1963; Martindale, 2005). Možemo pretpostaviti da je kreativni pristup onih koji su svakodnevno uključeni u umjetničku produkciju kudikamo složeniji, a obrada emocionalnog iskustva, kao i sadržaja primarnih procesa, zahtjevnija nego što se može detektirati izravnim izlaganjem podražaja koji ilustracijama pretendiraju evocirati određeni emocionalni doživljaj. O eventualnom utjecaju emocionalnog doživljaja na kreativni proces umjetnika posredno nam govori različito variranje koeficijenta kreativnosti kod studenata umjetnosti i produkcije u odnosu na emociju žalosti, što je ujedno i jedina značajna interakcija kada su u fokusu analize pojedinačne kvalitete emocija. Rezultati pokazuju da kreativnost umjetnika pokazuje tendenciju porasta 
kada izlagane fotografije izazivaju žalost $u$ većem stupnju, a kreativnost studenata produkcije raste već kada se izlažu sadržaji koji evociraju žalost srednjeg stupnja, dok s daljnjim povećanjem dolazi do mnogo blažeg porasta. Indikativno bi stoga bilo provjeriti nalaze s većim uzorkom umjetnika, jer postoji mogućnost da snažniji doživljaj žalosti ipak prati porast njihove kreativnosti, mada se dinamika procesa izvjesno razlikuje od kolega sa produkcije čija je kreativnost mnogo osjetljivija na emocionalni doživljaj i znatno se mijenja pri variranju u stupnju izraženosti valencije i uzbuđenosti kao i različite kvalitete emocija.

Izdvajanje studenata umjetnosti u odnosu na opću studentsku populaciju očekivano je, mada ne i razlike u odnosu na kolege s produkcije. Naime, mogli bismo očekivati da studenti produkcije po rezultatima premošćuju umjetničku i neumjetničku populaciju, u odnosu na mjerene varijable, a dobili smo nešto drugačiju sliku. Po povezanosti kreativnosti i bliskosti studenti VISER-a su bliži studentima umjetnosti, a po povezanosti kreativnosti s dimenzijama i kvalitetama emocija približavaju se studentima produkcije, ostajući tako "uglavljeni" između dva "suprotstavljena tabora". Podsjećamo pritom da se ta dva "tabora" ne razlikuju međusobno po stupnju kreativnosti. Oba FDU poduzorka pokazuju visoku kreativnost, znatno višu od opće studentske populacije, ali je ona izgleda potaknuta različitim mehanizmima. Moglo bi se zaključiti da kreativni proces kakav je detektiran kod pripadnika opće populacije, može biti diferenciran na više specifičnih pristupa zavisno od obuke, vokacije, različitih kognitivnih stilova i motivacijskih faktora. Dok su studenti umjetnosti stimulirani novinom, stožer kreativnog procesa kod studenata produkcije krije se u emocionalnom doživljaju. Razlog može biti u tome što su studenti produkcije osjetljiviji na stimulaciju koja dolazi iz okoliša. S jedne strane to može biti posljedica ekstravertnosti, a s druge strane i višeg empatijskog potencijala koji ih povezuje s drugima i potiče njihovu kreativnost. Za razliku od njih studenti umjetnosti više su okrenuti sebi i obuzeti vlastitim interesima u estetskom doživljaju (Silvia, 2005), a prednost odnose kolativne varijable (Berlyne, 1971), dok se vanjski podražaji mogu koristiti kao izazov, ili kao oruđe narcističke gratifikacije kroz kreativnu produkciju. Detektirana razlika može se razumjeti i u svjetlu različitih kognitivnih stilova studenata umjetnosti i produkcije, za koje je potvrđeno da mogu značajno utjecati na dinamiku i ishode kreativnog procesa (Bubić i Erceg, 2015; Khandwalla, 1993; Kirton, 1976)

Ako se sada osvrnemo na polazište rada, uz uvid u dobivene rezultate, možemo sa sigurnošću potvrditi da postoji povezanost kreativnosti kako s bliskošću sadržaja i dimenzijama emocionalnog doživljaja, tako i s različitim kvalitetama emocija. Fotografije koje evociraju neugodne emocije specifične kvalitete, kao što su žalost, srdžba, strah i gađenje djeluju stimulativno i rezultiraju kreativnijim odgovorima, dok ugodne emocije, kao što je radost, rezultiraju nižim stupnjem kreativnosti. Također, potvrđena je pretpostavka da dimenzije i kvalitete emocionalnog doživljaja, kao i bliskost izlaganog sadržaja različito djeluju na izrazito kreativne osobe, u odnosu na pripadnike drugih populacija. U radu budućih umjetnika ključna je novina, jer 
je kreativnost kod njih negativno povezana s dimenzijom bliskosti, a pozitivno s emocijom iznenađenja, dok njihove ništa manje kreativne kolega, budući producenti, zanemaruju novinu, ali su zato potaknuti neugodnim sadržajima. Pripadnici opće studentske populacije mogu biti potaknuti i neugodnim i novim sadržajima koji iznenađuju, ali ne dovoljno da bi po kreativnosti parirali studentima s iskustvom u umjetničkoj produkciji. Mada su za potvrdu ovih nalaza potrebne daljnja istraživanja s većim i raznorodnijim uzorcima sudionika, dobiveni rezultati upućuju na mogućnost da dimenzije emocionalnog doživljaja i kvalitete emocija, kao i bliskost sadržaja različito djeluju na produkciju umjetnika ne samo u odnosu na pripadnike opće populacije već i u odnosu na druge izrazito kreativne pojedince koji su često njihovi najbliži suradnici. Stoga postoji osnova za zaključak da se kreativnost na različite načine može razvijati, a da uloga emocija u kreativnom procesu varira ovisno o različitim kognitivnim stilovima i motivacijskim faktorima koji uvjetuju njegove specifičnosti.

\section{LITERATURA}

Baas, M., De Dreu, C.K. i Nijstad, B. A. (2008). A meta-analysis of 25 years of mood-creativity research: Hedonic tone, activation, or regulatory focus? Psychological Bulletin, 134(6), 779-806. doi:10.1037/a0012815

Baumeister, R. F., Dale, K. i Sommer, K. L. (1998). Freudian defense mechanisms and empirical findings in modern psychology: Reaction formation, projection, displacement, undoing, isolation, sublimation, and denial. Journal of Personality, 66, 1081-1124. doi:10.1111/1467-6494.00043

Benjafield, J. G. (1997). Cognition. ( $2^{\text {nd }}$ ed.). Englewood Cliffs, NJ: Prentice Hall. doi: 10.1002/(SICI)1099-0720(199710)11:5<457::AID-ACP488>3.0.CO;2-1

Bergler, E. (1945). On a Five -Layer Structure in Sublimation. The Psychoanalytic Quarterly, 14, 76-97.

Berlyne, D. E. (1971). Aesthetics and psychobiology. New York: Appleton.

Bubić, A. i Erceg, N. (2015). Uloga kognitivnih stilova u razumijevanju kognitivnog funkcioniranja pojedinaca. Suvremena psihologija 18(2), 159-174.

Cacioppo, J. T., Berntson, G. G., Larsen, J. T., Poehlmann, K. M. i Ito, T. A. (2000). The psychophysiology of emotion. In R. Lewis i J. M. Haviland-Jones (Eds.), The handbook of emotions (2nd ed., pp. 173-191). New York: Guilford Press.

Carllson, I. (2002). Anxiety and Flexibility of Defence Related to High or Low Creativity. Creativity Research Journal, 14(3 i 4), 341-349.

Cohen, J. (1969). Statistical Power Analysis for the Behavioral Sciences. New York: Academic Press.

Čorko, I. (2003). Efekti zahtjeva za povećanjem kreativnosti vlastitog prijašnjeg učinka. Suvremena psihologija 6(2), 249-262.

Davis, M. (2009). Understanding the relationship between mood and creativity: A metaanalysis. Organizational Behavior and Human Decision Processes, 108(1), 25-38. 
Domino, G., Short, J., Evans, A. i Romano, P. (2002). Creativity and ego defence mechanisms: Some exploratory empirical evidence. Creativity Research Journal, 14, 17-25. doi:10.1207/S1532 6934CRJ1401_2

Ekman, P. (1992). Are there basic emotions? Psychological Review, 99, 550-553. doi:10.1037/0033-295X.99.3.550

Farley, F. (1985). Psychobiology and cognition: An individual differences model. In J. Strelan, F. Farley i A. Gale (Eds.), The biological basis of personality and behavior. (Vol 11, pp 1-36). Washington, DC: Hemisphere.

Feist, G. (1999). Affect in artistic and scientific creativity. In S. Russ (Ed.), Affect, creative experience, and psychological adjustment (pp. 93-108). Philadelphia: Brunner/Mazel. doi:10.4324/9781315784557

Friendly, M. (2016). Power Analysis for ANOVA Designs [Software]. Available from: http:// www.math.yorku.ca/SCS/Online/power/

Forgas, J. P. (2002). Toward Understanding the Role of Affect in Social Thinking and Behavior. Psychological Inquiry, 13(1), 90-102. doi:10.1207/s15327965pli1301_03

Freud, S. (1908). Creative writers and day-dreaming. PsycEXTRA Dataset. doi:10.1037/ e417472005-225

Fulgosi. A. (2005). Psihologija stvaralačkog mišljenja: od introspekcije do asocijacionizma. Suvremena psihologija, 8(1), 62-92.

George, J. M. i Zhou, J. (2002). Understanding when bad moods foster creativity and good ones don't: The role of context and clarity of feelings. Journal of Applied Psychology, 87, 687-697. doi:10.1037/0021-9010.87.4.687

Hirt, E. R., Melton, R. J., McDonald, H. E. i Harackiewicz, J. M. (1996). Processing goals, task interest, and the mood-performance relationship: A mediational analysis. Journal of Personality and Social Psychology, 71(2), 245-261. doi:10.1037/0022-3514.71.2.245

Houston, J. P. i Mednick, S. A. (1963). Creativity and the need for novelty. The Journal of Abnormal and Social Psychology, 66(2), 137-141. doi:10.1037/h0043197

Hulley, S. B., Cummings, S.R., Browner, W.S, Grady, D. i Newman, T. B. (2013) Designing clinical research: an epidemiologic approach. 4th ed. Philadelphia: Lippincott Williams i Wilkins; Appendix 6C, page 79.

Isen, A. M. (1993). Positive affect and decision making. In M. Lewis i J. Haviland (Eds.), Handbook of emotions (pp. 261-277). New York: Guilford.

Isen, A. (1998). On the relationships between affect and creative problem solving. In S. Russ (Ed.), Affect, creative experience, and psychological adjustments (pp. 3-17). Philadelphia: Brunner/ Mazel. doi:10.4324/9781315784557

Isen, A. M. (2005). Positive Affect. Dalgleish/Cognition and Emotion, 521-539. doi:10.1002/0470013494.ch25

Isen, A. M. i Baron, R. A. (1991). Positive affect as a factor in organizational behavior. Research in Organizational Behavior, 13, 1-53.

Izard, C. E. (2010). The Many Meanings /Aspects of Emotion: Definitions, Functions, Activation, and Regulation. Emotion Review, 2 (4), 363-370. doi: 10.1177/1754073910374661

Jamison, K. R. (1993). Touched with fire: Manic depressive illness and the artistic temperament. New York: Free Press. doi:10.4135/9781483349985.n388 
Kaufmann, G. i Vosburg, S. (2002). The Effects of Mood on Early and Late Idea Production. Creativity Research Journal, 14 (3-4), 317-330.

Khandwalla, P. N. (1993). An exploratory investigation of divergent thinking through protocol analysis. Creativity Research Journal, 6, 241-259.

Kirton, M. J. (1976). Adaptors and innovators: A description and measure. Journal of Applied Psychology, 61, 622-629.

Kim, E., Zeppenfeld, V. i Cohen, D. (2013). Sublimation, Culture, and Creativity. Journal of Personality and Social Psychology, 105(4), 639-666. doi: 10.1037/a0033487639

Klein, M. (1935). A contribution to the psychogenesis of manic-depressive states. International Journal of Psycho-Analysis, 16, 145-174; reprinted 1975 in The Writings of Melanie Klein. Vol. 1. London: Hogarth.

Kohn, M. (2016). Sample size calculators for designing clinical research [Software]. Available from http://www.sample-size.net/correlation-sample-size/

Kris, E. (1952). Psychoanalytic exploration in art. New York: International Universities Press.

Mandić, T. i Ristić, I. (2013). Psihologija kreativnosti. Beograd: Institut za pozorište, film radio i televiziju. Fakultet dramskih umetnosti Univerzitet umetnosti u Beogradu.

Marchewka A., Żurawski Ł., Jednoróg K., Grabowska A. (2014). The Nencki Affective Picture System (NAPS): introduction to a novel, standardized, wide-range, high-quality, realistic pictures database. Behavior Research Methods, 46(2):596-610. doi: 10.3758/ s13428-013-0379-1.2013

Martin, L. L. i Stoner, P. (1996). Mood as input: What we think about how we feel determines how we think. In L. L. Martin i A. Tesser (Eds.). Striving and feeling: Interactions among goals, affect, and self-regulation (pp. 279-301). Hillsdale, NJ: Erlbaum

Martin, L. L., Ward, D. W., Achee, J. W. i Wyer, R. S. (1993). Mood as input: People have to interpret the motivational implications of their moods. Journal of Personality and Social Psychology, 64(3), 317-326. doi:10.1037/0022-3514.64.3.317

Martindale, C. (2005). Biological biases of creativity. In R. J. Sternberg (Ed.). Handbook of creativity (pp.137-152). Cambridge, England: Cambridge University Press. doi:10.1017/cbo9780511807916.009

Mauss, I. B. i Robinson, M. D. (2009).Measures of emotion: A review. Cognition and Emotion, 23, 209-237.

Mehrabian, A. i Russell, J. A. (1974). The basic emotional impact of environments. Perceptual and Motor Skills, 38(1), 283-301. doi:10.2466/pms.1974.38.1.283

Milošević, M. i Ristić, I. (2017). Konstrukcija i validacija koeficijenta kreativnosti. Empirijska istraživanja u psihologiji XXIII. Filozofski fakultet. Beograd. 18.-20. 03. 2016

Milošević, M. i Ristić, I. (2016). Nov metodološki pristup studijama kreativnosti. In Medias Res časopis filozofije medija, 5(8), 1237-1250.

Mraz, W. i Runco, M. A. (1994). Suicide ideation and creative problem solving. Suicide and Life-Threatening Behavior, 24(1), 38-47.

Posner J., Russell J. A. i Peterson B. S. (2005). The circumplex model of affect: an integrative approach to affective neuroscience, cognitive development, and psychopathology. Development and Psychopathology, 17, 715-734. doi: 10.1017/S0954579405050340 
Plucker, J.A. i Begetto, R.A. (2004). Why creativity is domain general, why it looks domain specific, and why the distinction does not matter. In R.J. Sternberg, E.L. Grigorenko i J.L. Singer (Eds.). Creativity: From potential to realization. Washington, DC: American Psychological Association.

Ristić, I. i Milošević, M. (2017). Povezanost kreativne produkcije i emocionalnog doživljaja: Postajemo li kreativniji posmatrajući nove neprijatne slike? Primenjena psihologija, $10(3)$.

Rotenberg, A. (2010). Kreativnost i ludilo. Beograd: Clio.

Ruder, M. i Bless, H. (2003). Mood and the reliance on the ease of retrieval heuristic. Journal of Personality and Social Psychology, 85, 20-32. doi:10.1037/0022-3514.85.1.20

Runco, M. A. (1998). Tension, adaptability, and creativity. In S. W. Russ (Ed.), Affect, creative experience, and psychological adjustment (pp. 165-194). Philadelphia, PA: Brunner/ Mazel. doi:10.4324/9781315784557

Russ, S. (1993). Affect and creativity: the role of affect ad play in the creative process. Hillsdale, NJ: Lawrence Erlbaum Associates, Inc. doi:10.4324/9780203772621

Russ, S.W., Robins, A.L. i Christiano, B.A. (1999). Pretend play: Longitudinal prediction of creativity and affecting fantasy in children. Creativity Research Journal, 12(2), 129139. doi:10.1207/s15326934crj1202_5

Russell, J. A. i Mehrabian, A. (1977). Evidence for a three-factor theory of emotions. Journal of Research in Personality, 11(3), 273-294. doi:10.1016/0092-6566(77)90037-x

Shapiro, P. J. i Weisberg, R. W. (1999). Creativity and bipolar diathesis: Common behavioral and cognitive components. Cognition and Emotion, 13(6), 741-762. doi:10.1080/026999399379069

Showers, C. i Cantor, N. (1985). Social cognition: A look at motivated strategies. Annual Review of Psychology, 36(1), 275-305. doi:10.1146/annurev.ps.36.020185.001423

Silvia, P. J. (2005). What is interesting? Exploring the appraisal structure of interest. Emotion, 5, 89-102.

Sternberg, R. J., Grigorenko, E. L. i Singer, J. L., (Eds.) (2004). Creativity: From potential to realization. Washington, DC: American Psychological Association.

Tettamanti, M., Rognoni, E., Cafiero, R., Costa, T., Galati, D. i Perani, D. (2012). Distinct pathways of neural coupling for different basic emotions. NeuroImage, 59, 1804-1817.

Unkelbach, C., Fiedler, K., Bayer, M., Stegmüller, M. i Danner, D. (2008). Why positive information is processed faster: The density hypothesis. Journal of Personality and Social Psychology, 95(1), 36-49.

Vaillant, G. E. i Vaillant, C. O. (1990). Determinants and consequencesof creativity in a cohort of gifted women. Psychology of Women Quarterly, 14, 607-616. doi:10.1111/j.1471-6402.1990. tb00234.X

Viinikainen, M., Kätsyri, J. i Sams, M. (2011). Representation of perceived sound valence in the human brain. Human Brain Mapping, 33, 2295-2305.

Vosburg, S. K. (1998a). The effects of positive and negative mood on divergent thinking performance. Creativity Research Journal, 11(2), 165-172. doi:10.1207/s15326934crj1102_6

Vosburg, S. K. (1998b). Mood and the quantity and quality of ideas. Creativity Research Journal, 11(4), 315-324. doi:10.1207/s15326934crj1104_5 
Vosburg, S. i Kaufmann, G. (1998). Mood and creativity research: The view from a conceptual organizing perspective. In S. Russ (Ed.), Affect, creative experience, and psychological adjustment (pp. 19-39). Philadelphia: Brunner/Mazel. doi:10.4324/9781315784557

\title{
DISTURBING AND NEW CONTENT IN THE SERVICE OF CREATIVITY: WHAT MAKES ART STUDENTS DIFFERENT FROM OTHERS?
}

\begin{abstract}
Psychodynamic assumptions that unpleasant and new content can stimulate creativity have been partially confirmed by empirical research. However, it is questionable, in which way the familiarity of content, the particular dimensions of the emotional experience and the qualities of emotions affect the production of highly creative individuals such as art students, and whether their creative process shows a certain level of peculiarity. In this research, the degree and type of correlations between the creativity of the response, and the qualities of emotions (happiness, sadness, fear, anger, surprise and disgust), the dimensions of the emotional experience (valence and arousal) and the familiarity of content were examined with different student populations. The experiment was performed with 59 students, and 40 photos were selected for visual stimulation, so that the values of the dimensions and qualities of the emotional experience were systematically varied. Students were exposed to the photos and were asked to rate the familiarity of their content, and subsequently to make the most creative title for each of them. The creativity of the titles was measured by coefficients of creativity and uniqueness, based on the originality assessment. The results confirm the statistical significance of moderate negative correlations between creativity and familiarity of content, valence, and happiness; moderate positive correlations between creativity and arousal, sadness, fear, anger, surprise and disgust, as well as process specificities of the art students, for whom novelty and surprise take the lead over other qualities and dimensions of emotional experience.
\end{abstract}

Key words: creativity, primary emotions, familiarity of content, dimensions of emotional experience, artistic production 